\title{
A fiscalização que mais se deseja: a inspeção do ensino na Capital do Império Brasileiro
}

\section{Resumo}

O objetivo deste artigo consiste em analisar o funcionamento do serviço de inspeção da instrução na Capital do Império, Rio de Janeiro, a partir da instituição da Lei Geral do Ensino de 1827; da lei que regulou as Câmaras Municipais em 1828 - que delegou a elas a função de inspeção das escolas de primeiras letras -; e do Regulamento de Instrução Primária e Secundária da Corte de 1854. Para tanto, realizei uma investigação em torno das diferentes instâncias criadas ou acionadas para atuarem na fiscalização das escolas, assim como dos sujeitos envolvidos em ações fiscalizadoras. A reflexão dá ênfase às tensões e disputas produzidas no exercício da inspeção ou pela submissão desse serviço ao "desleixo e abandono", em um momento em que se atribuía a ele a solução para muitos problemas da instrução pública, bem como um papel estratégico no interior de um projeto civilizador por meio da escolarização da população.

Palavras-chave: Educação. Brasil. História. Inspeção Escolar.

\section{Para citar este artigo:}

BORGES, Angélica. A fiscalização que mais se deseja: a inspeção do ensino na Capital do Império Brasileiro.

Revista Linhas. Florianópolis, v. 18, n. 36, p. 09-40, jan./abr. 2017.

\author{
Angélica Borges \\ Universidade do Estado do Rio \\ de Janeiro - UERJ - Rio de \\ Janeiro/Brasil \\ angelicaborgesrj@gmail.com
}




\title{
The most wanted supervision: the inspection of education in the Brazilian Empire Capital
}

\begin{abstract}
This study intends to analyze the operation of the inspection service in Education, in the capital of the Brazilian Empire, Rio de Janeiro, as of the enforcement of the 1827 General Law of Education; under the law that regulated the Municipal Chambers in 1828 which delegated them the inspection function of the primary schools; and under the 1854 Primary and Secondary Instruction Regulation of the Imperial Court. Therefore, the research has been made regarding the different instances, created or activated for the inspection of schools and of the subjects involved in the inspection process as well. The reflection emphasizes the tensions and disputes produced in the inspection exercise or by submission of this service to "neglect and abandonment", in a moment in which the solution of many problems of the public education, as well as a strategic role within a civilizing project through schooling of the population, was assigned to this service.
\end{abstract}

Keywords: Education. Brazil. History. School Inspection. 
Este estudo pretende apresentar uma análise do funcionamento do serviço de inspeção na Capital do Império, Rio de Janeiro, a partir da instituição da Lei Geral do Ensino de 1827; da lei que regulou as Câmaras Municipais em 1828 - que delegou a elas a função de fiscalizar as escolas de primeiras letras -; e do Regulamento de Instrução Primária e Secundária da Corte de 1854. O estudo está organizado em dois movimentos. No primeiro, busco refletir a dinâmica de construção de um aparato de inspeção na primeira metade do século XIX, observando várias leis e ordens, bem como a complicada relação entre diferentes instâncias de governo no exercício da inspeção. No segundo movimento, busco compreender os efeitos do Regulamento de 1854 na tentativa de organizar um "centro de inspeção".

Para tanto, realizei uma investigação em torno das diferentes instâncias criadas ou acionadas para atuarem na fiscalização das escolas, bem como dos sujeitos envolvidos em ações fiscalizadoras. A reflexão dá ênfase às tensões e disputas produzidas no exercício da inspeção ou pela submissão desse serviço ao “desleixo e abandono”, em um momento em que se atribuía a ele a solução para muitos problemas da instrução pública, bem como um papel estratégico no interior de um projeto civilizador por meio da escolarização da população.

O repertório de fontes utilizadas no trabalho engloba documentos manuscritos da Série "Instrução Pública" do Arquivo Geral da Cidade do Rio de Janeiro; decretos da Coleção de Leis do Império; relatórios dos ministros do Império; relatórios da Inspetoria Geral de Instrução Primária e Secundária da Corte; e periódicos do século XIX. Os documentos pesquisados e produzidos pelo funcionamento do serviço de inspeção da instrução ajudam a constituir uma memória em torno de um dispositivo e de seus efeitos, relatando visitas, queixas, solicitações e outros procedimentos. Compõem um poder transmitido pela palavra impressa que captura a realidade e os sujeitos, objetivando-os pelas lentes daquele que escreve, do lugar de onde escreve, da função e do destino da escrita. Assim, o estudo parte da perspectiva de que o exercício de escrita pode ser entendido como componente de uma maquinaria disciplinar, que descreve e dá visibilidade a determinados sujeitos e, neste caso específico, à instrução, ao corpo docente e as suas práticas. A partir do que foi tornado visível, as instâncias do governo vão pensar as políticas da instrução e da profissão docente. 
Nesse sentido, aparecem inscritos discursos proferidos por diferentes sujeitos acerca da necessidade e do significado da inspeção do ensino, em diversas fontes do século XIX como relatórios do governo, periódicos e livros. Neles, podemos observar uma pauta de preocupações e de ações voltadas para o controle da educação do povo, sendo a inspeção sistemática do ensino uma estratégia imperativa a ser implementada de modo efetivo e eficiente.

Segundo Giglio (2006), a instrução pública elementar funciona como espaço de ligação entre povo e governo, como "espaço de implantação de um novo modelo de relações sociais que se está instaurando e que se caracterizará inicialmente como espaço de aprendizagem da civilidade, do comportamento disciplinado" (GIGLIO, 2006, p. 349)1. Para a autora, a inspeção parece ter sido um dispositivo que nasceu da necessidade de ampliar o poder de controle sobre os negócios e a população do Império². Dessa forma, os professores públicos deveriam se tornar aliados na "civilizadora missão de debelar a ignorância", como defendia o inspetor geral da instrução na Corte, Eusébio de Queiroz, no período aproximado de 1855 a 1865. Para garantir a construção e manutenção dessa aliança, o governo imperial almejava uma vigilância “forte e sistemática” sobre a corporação docente na Capital do Império.

\section{Entre decretos e ordens: processos de constituição da inspeção da instrução}

A instauração de dispositivos legais visando à normatização e regulamentação das atividades escolares no século XIX constituiu um processo permeado de brechas, itens não regulados e emergência de situações inesperadas. Aspectos que deram margens para as agências docentes e para os professores atuarem de modo criativo, tanto na fundamentação de discordâncias em relação às leis quanto na elaboração de suas

\footnotetext{
1 Ao estudar aspectos da inspeção escolar em Santa Catarina, Gonçalves também compreende "o movimento de constituição da inspeção escolar em forma de ação institucionalizada como parte integrante do projeto de construção de uma nação civilizada, na perspectiva burguesa possível da época" (GONÇALVES, 2004, p. 1).

${ }^{2}$ Para Giglio, a prática da inspeção se encontra circunscrita "a uma fórmula mais geral de civilização que articula o olhar à palavra - às leis, normas, regulamentos -, e a palavras às ações ou práticas de governo" (GIGLIO, 2006, p. 350). Ressalta, na Província de São Paulo, os vínculos existentes entre os dois modelos de inspeção, o da instrução e o da polícia, que apontam uma articulação entre diferentes milícias. Ao lado de uma milícia armada destinada "a vigiar as populações e a garantir as condições necessárias à administração da justiça" atuavam milícias "pacíficas" - párocos e mestres -, que buscavam "civilizar através da palavra e do olhar a rude população da província, numa verdadeira cruzada civilizatória" (Ibidem, p. 351).
} 
próprias normas. Em tais circunstâncias, cabe pensar o papel atribuído à inspeção bem como as condições de seu funcionamento em diferentes lugares do país.

Insere-se nessa questão o caso do professor público Simão Bernardino da Costa Passos, ao se recusar a dar início ao ensino mútuo. Simão alegava que não era possível aplicar o método porque sua escola não tinha condições para isso e que iria cumprir a determinação assim que o Ministro do Império colocasse em execução o artigo 5 da Lei Geral de 1827 (AGCRJ, Códice 10.4.2, f.6, 20/09/1833):

Para as escolas do ensino mútuo se aplicarão os edifícios, que houverem com suficiência nos lugares delas, arranjando-se com os utensílios necessários à custa da Fazenda Pública e os Professores, que não tiverem a necessária instrução deste ensino, irão instruir-se em curto prazo e à custa dos seus ordenados nas escolas das capitais. (AGCRJ, Códice 10.4.2, f. 6, 20/09/1833)

Os professores sabiam fazer uso dos recursos jurídicos para se defenderem ou fazerem exigências e, no caso de Simão, um professor com pelo menos dez anos de exercício, a experiência contava como fator importante na construção de argumentações. Considerando a legislação como um discurso historicamente construído e legitimado culturalmente, Gondra defende que a lei deve ser inscrita "no âmbito dos jogos de poder definidores de modelos sociais imaginados e desejados." (GONDRA, 2004, p. 2). Tais jogos de poder não se davam apenas no processo de elaboração das leis, mas também na sua aplicação, envolvendo diferentes instâncias do governo e da sociedade, que se desdobravam em outras disputas, produzindo tensões e também acordos estratégicos.

A Lei Geral de Ensino de 1827, primeira lei voltada para regular a instrução, não discriminava o procedimento de fiscalização, apenas indicava a quem cabia o serviço: “Presidentes em Conselho, a quem pertence a fiscalização das escolas". Faria Filho (2000) aponta que a Lei de 1827 caracteriza-se por ser contemporânea de um lento e paulatino

[...] fortalecimento de uma perspectiva político-cultural para a construção da nação brasileira e do Estado Nacional que via na instrução uma das principais estratégias civilizatórias do povo brasileiro, tal qual frações importantes da elite concebiam e propunham-se a organizar. 
Instruir as "classes inferiores" era tarefa fundamental do Estado Brasileiro e, ao mesmo tempo, condição mesma de existência desse Estado e da nação. (FARIA FILHO, 2000, p. 137)

Cabe ressaltar que por meio da Lei Geral de Ensino de 1827, ao definir regras para o acesso ao exercício docente, D. Pedro I criou mecanismos que submetiam "os futuros mestres e mestras à figura do Imperador ou àquelas as quais ele delega poderes; seus representantes imediatos" (GONDRA, 1997, p. 56), devendo os futuros mestres apresentar uma conduta modelar e regular.

No ano seguinte, outra lei, datada de $1^{\circ}$ de outubro de 1828 , regulou 0 funcionamento das câmaras municipais e as encarregou da inspeção das escolas:

Art. 70. Terão inspeção sobre as escolas de primeiras letras, e educação, e destino dos órfãos pobres, em cujo número entram os expostos; e quando estes estabelecimentos, e os de caridade, de que trata o art. 69, se achem por Lei, ou de fato encarregados em alguma cidade, ou vila a outras autoridades individuais, ou coletivas, as câmaras auxiliarão sempre quanto estiver de sua parte para a prosperidade, e aumento dos sobreditos estabelecimentos.

No caso da Capital do Império, a existência de leis e a atribuição de responsabilidade à Câmara Municipal quanto à inspeção das escolas parece não ter sido eficaz. Para evitar, segundo Cardoso (1999), que fiscais e professores burlassem a lei, o governo da Regência decidiu, em 5 de agosto de 1831, recomendar "à Sociedade Promotora da Instrução Elementar, no Rio de Janeiro, a colaborar com a inspeção das aulas de primeiras letras da Corte, 'um serviço de tanto interesse público, e tão análogo à sua patriótica instituição'.”(CARDOSO, 1999, p.126-127, aspas da autora).

Acionar uma sociedade para auxiliar no serviço demonstra uma tentativa do governo resolver a questão. No entanto, chama atenção o fato de professores públicos fazerem parte do quadro da referida sociedade, como Luis Antonio da Silva Barata, o que poderia instaurar uma situação inusitada de professores em exercício fiscalizarem a si mesmos. 
Não obstante a medida, o governo continuou pressionando a Câmara por resultados e, dois anos depois, a persistência do problema pode ser observada em uma portaria de 4 de março de 1836, que:

[...] ordena que a Câmara declare se tem satisfeito a disposição do Artigo 70 do seu Regimento, por via de algum dos seus Vereadores, a quem tenha cometido o encargo de fiscalizar as Escolas de primeiras letras, e se este lhe ha participado o estado regular, ou defeituoso em que as tem achado. Resolveu-se que se participasse ao Governo, que a Câmara tem incumbido aos seus Fiscais a inspeção sobre as Escolas, remetendo trimensalmente o resultado de suas informações. (CORREIO OFICIAL, 11/04/1836, n. 79, p. 314)

Os fiscais da câmara eram responsáveis por fiscalizar uma variedade de coisas e situações. As escolas seriam apenas mais uma entre tantas, mas com uma diferença. $O$ fato de não existir a possibilidade de "multar" a escola em situação irregular, como ocorria no comércio, por exemplo, ramo que era bastante vigiado, talvez causasse certo desinteresse em cumprir o papel de fiscalizar a escola com o rigor que o governo esperava.

Mesmo com as constantes pressões que as fontes sugerem ter existido, parece que o artigo não teve o cumprimento esperado, como denuncia o Correio Oficial:

Tendo mostrado a experiência que, não obstante o haver-se confiado às Câmaras Municipais [...] a fiscalização das Escolas Primárias, não se tem conseguido o desejado progresso em favor da educação da Juventude; antes pelo contrário se há observado, no que respeita às Escolas de Primeiras Letras desta Corte e Município, um total desleixo e abandono sobre um tão interessante objeto, que aliás deve necessariamente produzir uma péssima influência sobre a cultura moral e intelectual da mocidade em seus destinos futuros; e sendo por isso da maior urgência ocorrer quanto antes ao remédio de tais males, estabelecendo uma eficaz e permanente fiscalização sobre a conduta, assiduidade, e mais obrigações dos Mestres das ditas escolas, dando-se-lhes uma norma fixa para regime do seu magistério, em harmonia com os princípios liberais e legislação em vigor, a fim de se preencherem os saudáveis fins da Carta de Lei de quinze de outubro de mil oitocentos e vinte e sete. (CORREIO OFICIAL, 28/03/1836, n. 69, p. 273) 
Por outro lado, o "total desleixo e abandono" com que a câmara era acusada de tratar o ramo da instrução pode indicar mais do que um desinteresse, mas também certa rivalidade ou revanche, diante das tentativas do governo de esvaziar os poderes municipais. Nesse mesmo número do Correio Oficial publica-se um decreto com as "Providências e determinações sobre as Escolas de Primeiras Letras desta Corte e Município”, de 15 de março de 1836, por meio do qual foi criada a função de diretor das escolas. Nomeado pelo Ministro do Império, o diretor tinha como função:

[...] a fiscalização e inspeção das Escolas de Primeiras Letras desta Corte e Município, que lhe ficam subordinadas, e a respeito das quais fará observar, não só as presentes Providências e Determinações, mas também todas e quaisquer Instruções ou Ordens, que de futuro lhe forem pelo Governo transmitidas. (CORREIO OFICIAL, 28/03/1836, n. 69, p. 273)

No dia seguinte ao decreto, 16 de março, Joaquim José da Silveira foi nomeado para o cargo de diretor, ficando na função até 1854, quando a Reforma Couto Ferraz criou o posto de inspetor geral. Joaquim havia sido, segundo a portaria de nomeação, ex-oficial maior da extinta mesa do Desembargo do Paço. Coube a ele, além das obrigações de visitar escolas e averiguar o cumprimento das normas por parte dos professores, nomear substitutos, assistir a exames e concursos de provimento de cadeiras.

O decreto também atribuía ao diretor o papel de "obrigar" os mestres a terem um livro de matrícula rubricado e encerrado por ele, onde deveriam constar os nomes dos alunos, datas de entrada e saída, pátria, idade, nome dos pais, observações a respeito de comportamento, aplicação e progressos e que remetessem, a cada três meses, uma relação completa dos alunos, bem como o método que usa e o ensino das matérias previstas, a obrigação de punir a insubordinação dos discípulos, devendo encaminhar os casos mais graves ao diretor. Embora a criação do diretor tenha sido encarada como uma solução aos problemas da inspeção, os fiscais da câmara continuaram atuando nas escolas até a reforma de 1854, como indicam os vários documentos assinados por eles na Série Instrução Pública do Arquivo Geral do Rio de Janeiro (AGCRJ). 
O decreto era mais um dispositivo para dar ordem a um espaço considerado desorganizado, desregrado, mas, sobretudo, sem vigilância e que, portanto, poderia estar a serviço de interesses contrários ao que o governo esperava de uma instituição escolar. Mas, apesar da lei que criava a autoridade do diretor, a querela acerca do papel da câmara continuava, posto que a norma de 1836 não revogava a função fiscalizadora da câmara na Corte. Em 1836, um texto da sessão chamada "Artigos não oficiais", do Correio Oficial, assinado apenas por G. comenta o decreto:

Desde muito tempo que sentíamos a necessidade de algumas providencias a respeito da instrução primária, cuja fiscalização cometida pela Lei ao Ministro dos Negócios do Império, e às câmaras municipais, não podia ser exercida com utilidade publica: essa necessidade acaba de ser satisfeita no Município da Corte [...]

Que o Ministro e Secretário de Estado dos Negócios do Império, tenha a Inspeção suprema não só sobre os Estabelecimentos Gerais de instrução, nós perfeitamente entendemos isso, e com isso concordamos; mas que desça às miudezas de assistir a exames de vigiar individualmente na maneira porque os professores cumprem com suas obrigações, no adiantamento dos alunos, e na avultada despesa que se faz neste ramo da Administração publica, é o que não nos parece compatível com os muitos, variados, e importantes objetos de que ele tem de ocupar-se em um país nascente como o nosso, onde pouco se tem feito, ou, para melhor dizer, tudo se acha ainda por fazer, do muito que é necessário para dar-se algum impulso a coisas de vital interesse, que tem estado esquecidas, ou inteiramente ignoradas. Mas, a câmara municipal, o que faz, perguntará alguém? Em verdade ela pouco, ou nada pode fazer nesta matéria. Em primeiro lugar as Câmaras não são Corporações científicas, que possam exercer com vantagem a fiscalização que mais se deseja; em segundo lugar essa mesma fiscalização que exercem, elas a cometem a seus Fiscais, que menos ainda sabem, ou podem desempenhá-la. Para prova desta verdade basta refletir que no longo espaço de anos, decorrido desde a data da Lei que organizou as Escolas primarias, até hoje, ainda uma só reflexão útil, não veio sobre este assunto ao Governo. Todo o seu expediente a este respeito tem quase limitado a representar a necessidade do estabelecimento de alguma Escola, e a atestar a frequência dos Professores; para se obter mesmo o número de alunos, tem se feito por vezes necessária a expedição de repetidas ordens. Um golpe de vista sobre os mapas que tem acompanhado os relatórios desta repartição; convencem desta verdade. Tem-se forcejado pela maior perfeição, sem ter sido jamais possível obtêla. (CORREIO OFICIAL, 5/04/1836, n.74, p. 296, grifos meus) 
A crítica à incapacidade da câmara de exercer a "fiscalização que mais se deseja" por meio de seus fiscais medíocres, diante de um ministro competente, mas por de mais ocupado com os negócios do país para "descer às miudezas", demonstra as tensões existentes entre as duas instâncias de poder.

Atuação que embora fosse vista como ineficiente e realizada por fiscais que não "saberiam" desempenhá-la, como acusa o artigo, não se dava sem tensões e atritos com os professores, o que sugere que, se não fiscalizavam da forma esperada pelo governo, exerciam algum tipo de inspeção a ponto de incomodar os mestres. O Diário do Rio de Janeiro, de 25/08/1843, traz a representação do professor Estevão José Pires, da freguesia de Guaratiba, dirigida à Câmara, em que se queixa do fiscal por se negar a lhe dar o atestado de frequência, documento primordial para o recebimento do salário. A atitude do fiscal demonstra a delicada relação imposta aos professores que ficavam à mercê das ingerências políticas de um indivíduo que ocupava um cargo considerado inferior na escala do funcionalismo público, mas dotado de um poder que não era desprezível.

O acionamento do poder de que dispunham os fiscais poderia ocorrer, por exemplo, na esfera das artimanhas políticas que deixariam os professores em situações delicadas, como a denunciada pelo professor João José Pereira Sarmento da freguesia de Santana (DIÁRIO DO RIO DE JANEIRO, 14/06/1832, n.9, p.55). O professor relata que, atendendo a um pedido feito "polidamente" pelo fiscal, entregou-lhe de "boa fé" uma listagem de nomes de alunos, pais e endereços. Mas depois percebeu que ele seria seu "gratuito inimigo" e estaria divulgando falsas informações pelas as quais o professor alega que não poderia sofrer "quebra de crédito e honra". Sarmento também declara não reconhecer o poder de fiscalização do dito fiscal, questionando sua autoridade em razão da Lei de 1827 não atribuir ao cargo dele a inspeção das escolas e, do artigo 70, da Lei das câmaras municipais, não “derrogar explicitamente” tal condição.

A publicação da nota em jornal de grande circulação sugere que os efeitos gerados pelas intrigas do "fiscal inimigo" poderiam ter arranhado sua imagem pública na sociedade. Moralidade e idoneidade eram requisitos fundamentais para o exercício da profissão e em nome delas seria preciso ampliar a divulgação de sua defesa por meio de um recurso de maior alcance. 
Mesmo com a ação conjunta (não necessariamente coordenada) dos fiscais das câmaras e do diretor, os efeitos esperados não eram alcançados. Assim, um aviso de 1844 da Câmara Municipal confiou, igualmente sem sucesso, aos párocos e juízes de paz a fiscalização, buscando "passar a diante" a função (Relatório do Ministro do Império de 1850, p. 13). Documentos registram uma evidente preocupação do governo com o fato dos professores exercerem o ensino sem inspeção, o que parecia caracterizar um perigo aos planos de constituição de um estado nacional ordeiro e civilizado que passava pela ordenação e civilização das práticas escolares.

Até 1854 , outras normas foram instituídas por meio de decretos. Algumas não tratavam diretamente da instrução, mas se estendiam a ela, como o regulamento da Secretaria dos Negócios do Império, com uma versão de 1843 e outra de 1844. O regulamento estabelecido pelo decreto n. 346, de 30 de março de 1844, organizava o expediente em seis seções; a segunda seção era responsável pelas áreas da polícia, saúde, obras e pela instrução pública. Uma das atribuições dizia respeito a um dispositivochave das regras de governamentalidade: a estatística.

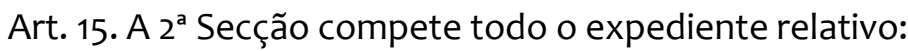

$1^{\circ}$ Ao provimento dos lugares de Diretores, Lentes, e mais Empregados dos Estabelecimentos Gerais de Instrução Pública, e suas dependências, que não forem subordinados a outro Ministério: ao de Professores das Aulas de Instrução Secundaria, e de Mestres de Instrução Primária; ao dos Empregados da Biblioteca Publica, do Museu Nacional, dos Jardins Botânicos, Escola de Agricultura, Academia das Belas Artes, Colégio de Pedro Segundo, e quaisquer outros Estabelecimentos de Instrução no Município da Corte; bem assim ás demissões, jubilações, aposentadorias, recompensas do pessoal dessa Instrução, e aos Estatutos, e Regulamentos de todos os referidos estabelecimentos Científicos, e Literários, e criação de outros novos.

$2^{\circ}$ A formação da Estatística de todas as Aulas, e Escolas, tanto públicas, como particulares, existentes no Império, à exceção das que se acharem a cargo de outro Ministério; demonstrando a respeito das primeiras o lugar, em que cada uma delas está colocada; a natureza, método, e livros do ensino; nome, estado, vencimento, assiduidade, e comportamento moral, e politico do Professor; finalmente o número, e aproveitamento dos alunos em cada ano; e a respeito das particulares as mesmas circunstancias, com exclusão porém do vencimento dos Professores. 
A “Formação estatística" tão cobrada à câmara seria composta por números, mas também por informações sobre a escola e seu território, o ensino e materiais, e o professor, acerca do qual se deveria saber seu comportamento moral e político, sinal do envolvimento dos professores com política na primeira metade do século XIX, algo que era preocupante para o governo. O Ministro do Império, Carlos Leôncio de Carvalho, também afirma mais explicitamente, na segunda metade do século, em 1877, que os professores públicos não deveriam se envolver "nas lutas de que é arena a política" (Relatório do Ministro do Império de 1877, p. 24). Tais dados eram utilizados para elaboração dos relatórios pelo governo. Apesar das fontes apontarem a complicada produção de dados e a publicação dos mesmos nos relatórios oficiais, elas constituíam peça fundamental dos procedimentos de governamentalidade.

\title{
A Reforma de 1854: uma tentativa de organizar um "centro de inspeção"
}

No que concerne à regulação do ensino e, mais especificamente, à própria organização da inspeção, Luiz Pedreira do Couto Ferraz emerge como uma figura destacada. Ele foi responsável pelas reformas na Província do Espírito Santo (1848), na Província do Rio de Janeiro (1849) e no município da Corte (1854).

\begin{abstract}
Bacharel, monarquista, conservador e homem de governo constituem-se em alguns dos traços que podem ser atribuídos a Couto Ferraz. Traços que o instituem em uma posição bem determinada, condição para que fosse indicado para o exercício das funções que desempenhou na vida pública: Presidente de duas Províncias e Ministro dos Negócios do Império, para indicar as que mais interessam a este trabalho, visto que é investido dessas funções que procura regulamentar a instrução primária e secundária, entre 1848 e 1854, nas Províncias do Espírito Santo e Rio de Janeiro e também na Corte. (GONDRA; TAVARES, 2004, p. 1)
\end{abstract}

Segundo Gondra e Tavares (2004), “a análise das características de três regulamentos permite associá-los a um processo reformador que objetivava, em domínios distintos, "levar a nação à luz da modernidade”" (GONDRA E TAVARES, 2004, p. 1). As iniciativas reguladoras da instrução, nesse sentido, visavam forjar um modelo de escola moderna e a inspeção constituía importante ferramenta nesse processo. 
O Regulamento da Instrução Primária na Província do Rio de Janeiro, estabelecido por Couto Ferraz, enquanto Presidente da Província, em 1849, possui um capítulo intitulado "Inspeção e governo das escolas", formado por oito artigos. Mattos (2004) destaca que Couto Ferraz reorganizou o sistema de inspeção acompanhando de perto a experiência francesa. Para o autor, esperava-se que os inspetores colocassem os professores em contato "físico" com os dirigentes "mais próximos" e estabelecessem entre ambos um "contato moral e intelectual", fazendo tal investimento parte dos esforços para a construção de uma "escola governamental”.

Cinco anos depois, o Regulamento da Instrução Primária e Secundária do Município da Corte foi instituído por Luiz Pedreira do Couto Ferraz, em 1854, na condição de Ministro dos Negócios do Império. A reforma estava prevista desde 1851 e foi realizada no âmbito do chamado gabinete de conciliação (1853-1856), podendo ser entendida como uma resposta aos “dramas da sua época” (GONDRA, 2001). Em relatório publicado em 20/04/1854, Couto Ferraz apresenta uma espécie de "diagnóstico do quadro educacional que precisava ser alterado, em torno do que o código jurídico deveria incidir, de modo a corrigir o existente" (GONDRA, 2001, p. 55). As preocupações consideradas na produção do regulamento foram assim expostas:

[...] eram ideias essenciais da reforma as seguintes: vulgarizar e estender o ensino público, organizar melhor o magistério, dando vantagens no presente e segurança no futuro aos professores, mas exigindo deles também mais aptidão e maior zelo; preparar bons professores; regular as condições do ensino particular; e chamar para um centro de inspeção por parte do Governo os colégios e estabelecimentos de educação da Capital do Império. (Relatório do ano de 1853, p. 62, grifos nossos)

Couto Ferraz acreditava ter criado "uma inspeção forte e sistemática para todos os estabelecimentos de instrução primária e secundária, assim públicos, como particulares." A inspeção teve uma considerável relevância, pois pode ser considerada “peça determinante na implementação da reforma, fazendo supor a existência de uma completa e fina sintonia entre o ministério e a inspetoria" (GONDRA, 2001, p. 57).

O Regulamento da Instrução Primária e Secundária do Município da Corte de 1854 arquitetou uma aparelhagem de fiscalização, por meio da criação de uma repartição 
chamada Inspetoria Geral de Instrução Primária e Secundária da Corte (IGIPSC); da composição de um quadro de agentes fiscalizadores; da produção de relatórios por ministros e inspetores registrando práticas discursivas a respeito do magistério; e do funcionamento das Conferências Pedagógicas, entendidas como um instrumento de inspeção e de controle de ideias na corporação docente (BORGES; GONDRA, 2005).

Couto Ferraz igualmente assinala ter definido a obrigação dos professores primários e secundários, "sujeitando-os a uma disciplina rigorosa, mas ilustrada", pretendendo "escoimar o ensino, tanto dos ineptos, como dos desleixados no cumprimento de seus deveres." ${ }^{3}$ Entre outras medidas, visando assegurar a dedicação dos professores ao ensino, o regulamento proibiu o professor público de exercer emprego administrativo sem autorização do inspetor geral ou qualquer profissão comercial ou industrial. A proibição procurou garantir por meio da lei uma situação que Nóvoa (1991), em seu modelo de análise, definiu como primeira etapa do processo histórico de profissionalização docente "exercício a tempo inteiro (ou como ocupação principal) da actividade docente", não a encarando como atividade passageira, mas sim como à qual dedicam parte importante da sua vida profissional.

A inspeção deveria estar atenta aos professores públicos que por negligência ou má vontade não cumprissem "bem os seus deveres, instruindo mal os alunos, exercendo a disciplina sem critério, deixando de dar aula sem causa justificada por mais de três dias em um mês, ou infringindo qualquer das disposições deste Regulamento ou as decisões de seus superiores" (Art. 115). Os mestres flagrados estavam sujeitos a processos disciplinares e punições. Estavam previstas penas de admoestação, repreensão, multa de até $50 \$$, suspensão de exercício e vencimentos e perda de carteira. A pena de suspensão era imposta nos casos de reincidência, maus exemplos ou inculcação de maus princípios aos alunos e desrespeito às pessoas incumbidas da inspeção do ensino. A perda da cadeira ocorreria nos casos de condenação às penas de galés ou prisão com trabalho, por crime de estupro, rapto, adultério, roubo ou furto, "por algum outro da classe daqueles que ofendem a moral pública ou a Religião do Estado" e quando o professor fomentasse imoralidade entre os alunos (Art. 119).

\footnotetext{
${ }^{3}$ Relatório relativo ao ano de 1853, publicado em 1854, p. 63.
} 
Por meio de tais procedimentos, representantes do Estado Imperial almejavam conhecer, controlar e homogeneizar professores e práticas escolares. O projeto da civilização do povo e do progresso do país, por intermédio da instauração de uma ordem escolar, exigia moldar mestres exemplares. No entanto, para Nascimento, ao mesmo tempo em que o governo, na tentativa de conformação da profissão docente, instituiu mecanismos de controle por inspeção e vigilância que buscavam definir um "modelo" de professor para incorporá-lo entre os principais agentes do projeto social e político do Estado moderno, os "professores irão, lentamente, se constituindo enquanto corpo profissional, desenvolvendo uma identidade coletiva em certa medida contrária aos poderes do Estado" (NASCIMENTO, 2002, p. 2).

\section{O "centro de inspeção" em funcionamento: sujeitos e problemas}

Conforme o artigo primeiro do regulamento de 1854, a inspeção dos estabelecimentos públicos e particulares de instrução primária e secundária do município da Corte seria exercida pelo Ministro e Secretário d’Estado dos Negócios do Império ${ }^{4}$, pelo inspetor geral, pelo Conselho Diretor e pelos delegados de distrito. $\mathrm{O}$ inspetor geral contava com um secretário e uma repartição, a Inspetoria Geral de Instrução Primária e Secundária da Corte, na qual se concentravam os trabalhos da inspeção. Tais agentes eram responsáveis por uma cidade com estatuto de sede política do regime imperial e de residência oficial dos soberanos do Império brasileiro de acordo com a Constituição de 1824.

Segundo Berger (1965), a cidade do Rio de Janeiro "era dividida sob um aspecto eclesiástico em diversas freguesias ou paróquias, as quais limitavam os territórios de jurisdição religiosa, em princípio" (BERGER, 1965, p. 7). A cidade ficou desligada da província do Rio de Janeiro a partir do Ato Adicional de 12 de agosto de 1834, constituindo a Corte ou Município Neutro, cuja divisão territorial “compreendia um aspecto municipal,

\footnotetext{
${ }^{4}$ Entre as atribuições do Ministro dos Negócios do Império cabia nomear o inspetor geral e também inspecionar os estabelecimentos públicos e particulares da instrução primária e secundária. Em seus relatórios, observa-se a frequente reclamação de não conseguir fiscalizar a instrução por ter que se ocupar de outras atividades. Nos relatórios dos Ministros de 1854 a 1865, de forma geral, a abordagem da instrução na Corte se caracterizou como uma descrição superficial, que depois remete à leitura do relatório do inspetor geral.
} 
policial e religioso, que se entrosavam e se confundiam" (BERGER, 1965, p. 7). Daí o uso do termo freguesia para limitação dos atos administrativos ou religiosos.

Esta parte do estudo se concentra entre os anos de 1854 a 1865 que recobre a instituição do regulamento e a gestão do inspetor Eusébio de Queiroz. Nesse período, existiram 19 freguesias, listadas a seguir, com suas respectivas datas de criação: Candelária (1634), Irajá (1644), Jacarepaguá (1661), Campo Grande (1673), Ilha do Governador (1710), Inhaúma (1749), São José (1751), Santa Rita (1751), Guaratiba (1755), Engenho Velho (1762), Ilha de Paquetá (1769), Lagoa (1809), Santana (1814), Sacramento (1826), Santa Cruz (1833), Glória (1834), Santo Antônio (1854), São Cristóvão (1856) e Espírito Santo (1865).

No ano da Reforma de 1854, o ambiente da Corte, até então repartido em 17 freguesias, com discussões acerca da epidemia, da vacinação, da proliferação dos cortiços, do problema da falta de prédios escolares próprios e da escravidão encontravam-se em funcionamento 26 escolas públicas, sendo 17 para meninos e 9 para meninas, frequentadas por 909 alunos e 555 alunas $^{5}$. Em 1865, havia 44 escolas, sendo 27 para o sexo masculino e 17 para o feminino, havendo a matrícula de 1912 alunos e 1570 alunas $^{6}$.

A preocupação com a divisão eficiente dos espaços para melhor exercício da vigilância pode ser vista no relatório da IGIPSC relativo ao ano de 1855 . Eusébio de Queiroz assinala nesse documento que as freguesias divididas em três extensos distritos colocavam a cargo de cada delegado um grande número de estabelecimentos públicos e particulares, tornando "impossível o que deve ser exequível para conseguir-se algum melhoramento no ensino publico". Assim,

[...] deixando subsistir os distritos de fora da cidade com uma só freguesia cada um, dividiu as da cidade em cinco distritos em lugar de três, como anteriormente eram, deve-se esperar, e já o vamos experimentado, mais ativa vigilância da parte dos delegados; porquanto, tendo cada um menor extensão que percorrer o menor número de estabelecimento para inspecionar, mais pronta deve ser a sua ação, mais eficaz a sua autoridade, e mais benéfica sua influência; pode cada estabelecimento ser objeto de um estudo especial, e desse jeito poderão

\footnotetext{
${ }^{5}$ Relatório do ano de 1854 .

${ }^{6}$ Relatório do ano de 1865.
} 
provir para o ensino público mais profícuos resultados do que até agora se tem colhido. (p. 4)

A dificuldade de comunicação entre a inspetoria e os delegados de distrito, principalmente no que se refere às freguesias rurais, comprometia a realização de uma inspeção eficiente. A distância afetava, do mesmo modo, o deslocamento dos delegados que deveriam visitar escolas longínquas e ir à inspetoria para conferências ou para prestar contas. Encontram-se no AGCRJ diversos ofícios de delegados que acusam atraso no recebimento de comunicados da Inspetoria, muitas vezes ocorrendo a perda de prazos e datas de reuniões. O delegado da freguesia de Guaratiba, Antonio Xavier Balieiro, diante do problema, chega a suspeitar que os ofícios estivessem sendo extraviados: "talvez com o fim de me desabonarem para com V.Ex, por isso levo ao conhecimento de V.Ex para providenciar a respeito, na certeza de que não sou omisso em responder aos ofícios de V.Ex, suspeito porque já recebi um ofício de V.Ex. indo pelo correio e que fora aberto" (Códice 11.1.4, 21/03/1857, p. 2).

Nesse sentido, cabe ressaltar o funcionamento da secretaria da inspetoria que aparece constantemente descrita nos relatórios como uma repartição sobrecarregada de tarefas. Em relatório do ano de 1858, o inspetor Eusébio de Queiroz destaca que

\begin{abstract}
Esta repartição desempenha com regularidade todo o expediente da inspetoria geral, e do conselho diretor. Acha-se constantemente atarefada de trabalhos, que pela maior parte exigem habilitações especiais. Entretanto seus empregados não são remunerados com a devida equidade, como por varias vezes tenho representado. Seu pessoal consta ainda de um secretário, três amanuenses, e um porteiro ao mesmo tempo contínuo e correio.

Este, apenas suficiente para as exigências dos lugares que exerce, não pode encarregar-se da entrega de compêndios, livros, alfaias, e utensis, requisitados para o uso das escolas das freguesias de fora da cidade, serviço de ordinário feito a custo por particulares, mediante estipendio que quase sempre exageram. (p. 2)
\end{abstract}

Anos depois, para "regularizar" o serviço da secretaria, em 9 de agosto de 1872, o inspetor geral, José Bento da Cunha Figueiredo, elaborou instruções para o 
funcionamento da inspetoria, estabelecendo quatro divisões ${ }^{7}$ : Divisão do Conselho Diretor e dos empregados subordinados à inspetoria; Divisão do pessoal do ensino particular primário e secundário; Divisão de contabilidade; Divisão de arquivo e fornecimento de objetos. No relatório afirma que "De hoje em diante não fará vergonha o recinto de uma repartição pública de não pequena importância." (p. 22). Houve certa regularidade na defesa de uma profissionalização do serviço de inspeção. Tal defesa vem acompanhada de um diagnóstico negativo do quadro educacional o que, via de regra, é associado a uma espécie de fraqueza do poder, decorrente de sua organização precária, e de uma institucionalização incipiente.

No que concerne aos agentes fiscalizadores, cabe analisar a função e o exercício dos cargos de inspetor geral, dos delegados de distrito e do Conselho Diretor. O inspetor geral encontrava-se incumbido de inspecionar ou delegar a inspeção de todas as escolas, colégios, casas de educação e estabelecimentos de instrução primária e secundária públicos e particulares; expedir instruções para os exames dos professores e dos adjuntos; julgar infrações disciplinares relativas à imposição de penas de admoestação, repreensão, ou multa; propor ao governo gratificações extraordinárias, aumento de vencimentos para os professores públicos, criação de escolas primárias; indicar os indivíduos "competentemente habilitados" para o magistério público, os encarregados da inspeção do ensino, os que se habilitarem para professores adjuntos e os professores a serem jubilados. Também estava ao seu cargo coordenar os mapas e informações acerca da instrução primária e secundária que os presidentes das províncias deveriam remeter anualmente ao governo, apresentando um relatório do progresso comparativo entre as diversas províncias e o município da Corte. Um outro dispositivo instituído pelo governo estava sob sua responsabilidade: as Conferências Pedagógicas, as quais deveriam presidir e organizar o regulamento.

Nomeado por decreto, sem tempo de mandato definido, o cargo não podia ser exercido por professor ou diretor de estabelecimento público ou particular de instrução primária ou secundária. No período do entre 1854 e 1889 houve acentuada rotatividade na ocupação do cargo e alguns não chegavam a completar um ano na função. O inspetor Eusébio de Queiroz foi uma exceção, tendo ficado por cerca de dez anos (1855-1865). A

\footnotetext{
${ }^{7}$ Relatório do ano de 1872, p.68 e 69.
} 
movimentação de inspetores parece estar integrada à rotação geral observada em outras esferas do poder executivo, sintoma da economia política da época.

O inspetor Eusébio de Queiroz se formou bacharel pelo Curso Jurídico de Olinda em 1831. Exerceu os cargos de Juiz do Crime do bairro do Sacramento no Rio de Janeiro, Juiz de Direito da $1^{\mathrm{a}}$ Vara de Crime da Corte e foi o primeiro Chefe de Polícia da Corte quando nem tinha completado 21 anos de idade, e ficou no cargo por 11 anos. Também foi ministro da justiça, senador e membro do Conselho de Estado. Ao compor com o Ministro da Fazenda, Rodrigues Torres, e o Ministro dos Estrangeiros, Paulino Jose Soares de Souza, a formação da chamada "trindade saquarema", tornou-se responsável pela hegemonia conservadora que marcaria a política imperial por longo tempo.

A análise dos relatórios produzidos pelo inspetor demonstra uma preocupação do mesmo em descrever informações de modo organizado, seguindo as recomendações previstas nos artigos que regulavam a atuação do inspetor geral. Sua preocupação em redigir relatórios, trabalho que considerava de significativa importância, pode ser observada logo no primeiro, referente ao ano de 1855 e assinado em 15 de fevereiro de 1856. Afirma que quando um país, apesar dos esforços em direção ao progresso, não consegue obter os resultados esperados, volta sua atenção para a instrução e educação da mocidade e a reforma do ensino torna-se uma necessidade:

Nessas circunstâncias, um relatório da instrução pública, tendo de apresentar em toda a sua nudez os males de que todos se queixam, e poucos podem ou ousam sondar, e de propor os meios de mais prontamente remediá-los, é por sem dúvida trabalho de mais alta importância e do mais subido alcance. (p. 1)

Alguns pontos aparecem em todos os relatórios, talvez devido à constante troca de Ministro, a quem os relatórios eram entregues, demonstrando a permanência de determinados problemas e uma significativa preocupação com seus efeitos no funcionamento da instrução, entre os quais: as dificuldades para fazer relatórios na forma prevista, a falta de remuneração dos delegados de distrito, a inspeção incipiente dos delegados, a defesa da inspeção pelos párocos, os baixos salários e reduzido pessoal da secretaria (amanuense, porteiro, contínuo), a falta de um salão e de biblioteca na 
repartição da IGIPSC, a necessidade de escola normal e da formação de pessoal, a baixa remuneração dos professores, os problemas com asseio e limpeza das escolas, a falta de exercícios ginásticos, a falta de prédios adequados e próprios para as escolas, o não cumprimento do artigo 48 do regulamento e a realização de conferências pedagógicas.

Em todos os relatórios, estes itens são insistentemente abordados, apontando que pouco ou nada havia sido feito em relação aos problemas levantados pelo inspetor, não obstante as notificações regulares contidas nos relatórios. O fato ajuda a compreender o sentimento de impaciência ou insatisfação aparentemente demonstrado no relatório relativo ao ano de 1860 e assinado em 15 de fevereiro de 1861, no qual escreve várias expressões que indicam uma situação de reclamações repetitivas, da persistência dos problemas e da falta de providências. A atuação de Eusébio como inspetor será assinalada ao longo do trabalho na medida em que se encontra articulada à atuação de outros agentes da inspeção.

No caso dos delegados de distrito, eles eram nomeados pelo governo a partir de proposta do inspetor geral e não podiam exercer o magistério público ou particular, primário ou secundário. Tinham o papel de inspecionar, pelo menos uma vez mensalmente, as escolas públicas de seus distritos, averiguando se cumpriam os regulamentos e as ordens superiores, dando conta ao inspetor geral do que observavam e propondo-lhe as medidas que julgavam convenientes; de impedir abertura de escola ou colégio sem autorização; de visitar, ao menos uma vez em cada trimestre, todos os estabelecimentos particulares autorizados, observando se "são guardados os preceitos da moral e as regras higiênicas"; se o ensino dado não contrariava a "Constituição, a moral e as Leis"; receber e transmitir aos inspetores gerais participações e reclamações dos professores e, trimensalmente, o mapa dos alunos das casas de educação públicas e particulares; de preparar, sobre propostas dos professores públicos, e enviar ao inspetor geral, o orçamento anual das despesas das escolas, bem como remeter-lhe depois de verificadas, uma prestação de contas; e inventariar os utensílios de cada escola pública.

A falta de remuneração foi um problema recorrentemente levantado, pois os delegados exerciam o cargo gratuitamente, não recebendo nenhum tipo de salário. Diante da questão, Eusébio de Queiroz alertava que não se poderia "ser exigente e severo com funcionários que, em tudo que fazem, entendem prestar, e em realidade 
prestam, serviço desinteressado e gratuito" (Relatório do ano de 1858, p. 33). A falta de remuneração era algo que poderia prejudicar a eficiência da inspeção e comprometer a instrução pública e o projeto de escolarização da população.

Diante deste quadro e no interior de um movimento de uma inspeção mais profissionalizada, o Regulamento de 1879, instituído por Carlos Leôncio de Carvalho, pretendia estabelecer salário para os delegados. O problema da não remuneração, ao remeter à ideia de voluntariado, exime da exigência de um compromisso obrigatório, bem como autoriza o exercício de outra ocupação assalariada para o sustento pessoal ou familiar, tornando secundária a função de inspecionar o ensino.

A ocupação do cargo de delegado não apresentava rotatividade no âmbito dos distritos e freguesias. Importa ressaltar a necessidade dos delegados residirem na freguesia onde atuavam, visto que professores e famílias precisavam se dirigir à moradia do delegado para tratar de questões relativas à escola, fazer solicitações e encaminhar documentos. Uma suposta mudança na região de atuação poderia demandar a mudança da residência desse agente fiscalizador. Outros indícios sugerem igualmente que tais sujeitos eram figuras destacadas na localidade e mantinham determinadas relações de poder com seus habitantes. Tal aspecto pode ter sido usado como critério na escolha dos delegados de certas freguesias, bem como determinar sua permanência no cargo.

Tanto Eusébio quanto o inspetor geral Antonio Herculano de Souza Bandeira Filho (Relatório da IGIPSC do ano de 1883, p. 10), concebiam os delegados ou "inspetores escolares" como sujeitos que deveriam estar investidos de um determinado saber. Nessa perspectiva, a inspeção funcionaria como uma forma de compensar a falta de conhecimentos científicos, de contribuir com o trabalho feito na escola normal ou de compensar a sua ausência. Na concepção de Couto Ferraz um "conveniente corretivo" diante da falta de uma formação prévia dos professores. ${ }^{8}$ Desse modo, o delegado ou inspetor escolar não fiscalizaria com o intuito de incriminar, mas de orientar, animar os professores e trazer o progresso para o bem da instrução, cumprindo a função de “instruir o professor sobre o que este não sabe". Para isto, o inspetor escolar também deveria ser detentor de conhecimentos pedagógicos e ser versado em legislação escolar.

\footnotetext{
${ }^{8}$ Cf. UEKANE (2008).
} 
Ou seja, assumiria a figura daquele que não somente tem a autoridade e o poder de fiscalizar, mas, igualmente, a de educar.

Nesse sentido, merece destaque uma circular emitida pela IGIPSC aos delegados, em 1872, solicitando mapas e inventários das escolas, perguntando quais as "exigências" para o ensino público e particular de sua freguesia e o conceito que conferiam aos estabelecimentos da instrução, "a respeito de todos e de cada um per si”. A partir das concepções presentes nas respostas encaminhadas por tais agentes, é possível observar o modo como entendiam a instrução, sua função e o papel atribuído ao professor. 0 delegado Pedro José Pinto Serqueira da freguesia de Paquetá, por exemplo, responde alertando que é "leigo em tudo" e que seus conhecimentos foram adquiridos pela prática:

\begin{abstract}
Entendo que para o ensino marcado na $1^{\mathrm{a}}$ parte do art. 47 do regulamento de 14 de fevereiro de 1854 não se precisa de professores científicos, o que se precisa, sim, é um grande cuidado na sua escolha; que tenha boa moral, boa vontade e amor ao ensino, que por seus exemplos e explicações façam calar no ânimo das crianças o verdadeiro amor à religião e à pátria, respeito para com seus pais, veneração para os mais velhos e deveres para com a sociedade. A atual maneira de instruir não passa de fazer decorar e repetir artigos de livros, sem explicação ou definição, de forma que as crianças não passam de papagaios, e quando saem da escola, sabem, quando muito, fazer uma análise de gramática. (Relatório relativo ao ano de 1871, p. 62)
\end{abstract}

O discurso do delegado da llha de Paquetá mostra que as concepções em torno da educação defendidas pelos agentes da inspeção nem sempre estavam em sintonia com as de seus superiores, embora seja digno de atenção o fato de que também não havia consenso entre os dirigentes do governo. Cabe destacar que Pedro José Pinto Serqueira era farmacêutico e subdelegado de polícia. Apesar de não ter uma formação pedagógica e assumisse ser leigo no assunto, Serqueira era figura bastante influente na ilha. Dessa forma, importa assinalar que entre os delegados de distritos que atuaram no período de 1854 a 1865, encontravam-se 14 médicos, 8 bacharéis, 3 padres e um interino, 2 militares, 2 farmacêuticos, além de delegado e subdelegados de polícia e juízes de paz. A diversidade de ocupações também se traduz na diversidade de concepções de educação marcadas pelos debates travados no interior de cada campo profissional. 
No caso do Conselho Diretor, ele era composto pelo inspetor geral (presidente do conselho); reitor do Imperial Colégio de Pedro II; dois professores públicos e um particular de instrução primária ou secundária, que houvesse se distinguido no exercício do magistério; e por mais dois membros nomeados anualmente também pelo governo. Em 1857, com a divisão do Colégio de Pedro II em externato e internato, o estabelecimento passou a contar com dois reitores e, assim, o Conselho Diretor passou a ter a presença dos dois administradores. Também havia os membros substitutos para os dois professores públicos e um particular, e um outro substituto para os dois membros nomeados pelo Inspetor.

Por meio da composição do Conselho Diretor, Couto Ferraz afirma que "procurouse representar todos os interesses, quer do professorado; quer da Administração pública”. No que se refere aos indivíduos que haviam sido nomeados em 1854, expõe que as pessoas foram escolhidas pelo governo "umas por suas luzes na matéria, e outras por sua pratica no ensino" (Relatório do ano de 1853, p. 63).

De acordo com o Regulamento, cabia ao Conselho tomar parte em todos os negócios em que a sua intervenção fosse exigida, examinar métodos e sistemas práticos de ensino; designar e revisar compêndios; criar novas cadeiras; cuidar do sistema e matéria dos exames e julgar as infrações disciplinares a que estivessem impostas penas maiores que as de admoestação, repreensão ou multa, quer dos professores públicos, quer dos professores e diretores das escolas, aulas e colégios particulares: “Em geral será ouvido sobre todos os assuntos literários que interessem a instrução primária e secundária, cujos melhoramentos e progresso deverá promover e fiscalizar, auxiliando o Inspetor Geral."

Segundo relatório relativo ao ano de 1853, o Conselho Diretor começou os seus trabalhos no dia 5 de maio de 1854 . No ano seguinte, o Ministro do Império relata que:

O conselho diretor desde que se instaurou, sob a presidência do mui digno e ilustrado inspetor geral, tem constantemente se esmerado no desempenho de sua árdua missão, já elaborando trabalhos importantes para a realização das reformas que o governo iniciou pelo ministério a meu cargo no regulamento de 17 de fevereiro do ano passado, já procurando imprimir nas escolas, no colégio de Pedro $2^{\circ}$, e em todos os estabelecimentos de instrução, a direção que é necessária, afim de que 
não se malogrem as benéficas intenções do poder legislativo e do governo. (Relatório do ano de 1854, p. 72)

O inspetor Eusébio descreve a realização de vários trabalhos pelos Conselho: “A maior harmonia e melhor inteligência não tem cessado de existir entre todos os membros que o compõem, e devo, como homenagem à justiça, declarar que o mesmo zelo e a mesma solicitude os anima no intento de melhorarem o estado da instrução pública do país" (Relatório do ano de 1855, p. 2). Na fala do inspetor, observa-se um cuidadoso discurso para assegurar que os elogios eram feitos com razão. Em todos os relatórios que produziu, com exceção do ano de 1863, proferiu elogios ao Conselho Diretor destacando a regularidade de suas reuniões e "decidindo com critério e reflexão as questões sujeitas à sua deliberação, e tomando parte ativa e interessada em tudo quanto diz respeito à instrução, reinando a maior harmonia entre todos os seus membros" (1860, p. 2).

Apesar dos relatos de Eusébio asseverando a regularidade dos trabalhos do Conselho, posteriormente, em 1868, recebeu críticas do Ministro Paulino Soares de Sousa que acusou seus membros de serem "todos incumbidos de dizer, e nem um de fazer. Seguiu-se a regra da administração francesa de consultarem uns e obrarem outros." (Relatório do Ministro, p.25, 1868). Em relatório de 1871, o Ministro João Alfredo Correa de Oliveira ao destacar que os membros do Conselho também não eram remunerados, assinala: "As reuniões do Conselho Diretor, composto de cidadãos que servem gratuitamente, com louvável boa-vontade, não tem sido tão frequentes e eficazes como fora para desejar" (p. 21).

A partir de então, houve um aumento da reclamação de que o número de membros do Conselho estava reduzido ou insuficiente. Em relatório relativo ao ano de 1873, o inspetor Antonio Felix Martins enfatiza que, entre as tarefas do expediente do Conselho, "se avultam sobremodo petições de candidatos a títulos de habilitação mediante dispensa de exames" (p. 5). Relata que em razão do reduzido número de membros, que inclusive já possuíam outras ocupações, o Conselho não podia se reunir tantas vezes como demandava a quantidade de serviço. Por isso, o inspetor defendeu a realização de uma "conveniente" organização, aumento de pessoal sem impedimento de “ocupações estranhas que o possa distrair do que lhe for confiado” e justa remuneração. 
Assim, importa dar evidência às ocupações e profissões exercidas pelos membros do Conselho Diretor. Entre os vários sujeitos que foram membros do Conselho Diretor que atuaram no período de 1854 a 1865, podemos encontrar 10 bacharéis, 8 médicos e 2 eclesiásticos.

A continuidade da política de nomeação para os cargos de inspeção, acrescida do fato de certos cargos não possuírem remuneração, aponta a existência de uma política de troca de favores. Villela (2000) ressalta acerca da figura do "inspetor paroquial" que o “caráter não remunerado do cargo evidenciava a intenção de cooptar esses indivíduos como forma de garantir sua adesão ao acenar com possíveis benesses no futuro" (VILLELLA, 2000, p. 125). Os sujeitos que se destacassem no exercício desta função, seriam preferidos pelo presidente da província para algum emprego público ou recomendados ao governo imperial para receberem remunerações honoríficas.

A partir disso, percebe-se o estabelecimento de determinadas relações de poder marcadas pela interdependência e disputas de espaços. Elias (1993) aponta uma vinculação entre os controles individuais e os controles do outro, de maneira a possibilitar a permanência de relações funcionais entre os seres humanos (economia das pulsões). Considerando-se os arranjos dos quadros da inspetoria, podem-se observar as relações de interdependências, as tensões que tais arranjos poderiam provocar entre os grupos que disputavam o poder e as mudanças no equilíbrio de força que ocorriam quando este arranjo era alterado, por exemplo, por meio da queda de um gabinete no governo, situação frequente em determinados momentos no império brasileiro e que demonstra as tentativas de se manter o equilíbrio de poder. ${ }^{9}$

O destaque dado à presença de sujeitos com diferentes profissões e ocupações possui o intuito de enfatizar que não somente o Estado participa deste processo, mas também outras instâncias, em graus e formas diferenciadas, que fazem funcionar dispositivos de controle, contribuindo para conformação da profissão docente. É possível

\footnotetext{
${ }^{9}$ Segundo Martinez (1997), a direção do Ministério do Império, nos anos 1870, até 1878 foi formada pelo grupo considerado conservador, sendo prosseguidos pelos liberais. Já os anos 1880 representaram um momento de instabilidade política, se comparados ao período anterior, devido a frequentes quedas de gabinetes, com alternância entre os ditos liberais e conservadores. Em nove anos, alteram-se oito ministérios. Essas disputas acirradas e instáveis que se tratavam pelo poder se faziam presentes, consequentemente, nas "disputas em torno de ideias educacionais e projetos de instrução popular" (MARTINEZ, 1997, p. 59).
} 
observar a participação de diferentes instâncias da sociedade imperial nas engrenagens da aparelhagem de fiscalização, organizada pela Inspetoria Geral de Instrução Primária e Secundária da Corte (IGIPSC). Desse modo, destaca-se a presença de médicos, bacharéis, clérigos, militares, farmacêuticos e membros da ordem policial, representantes de instituições que exerceram intervenções educativas na sociedade, a partir de projetos, muitas vezes, forjados no calor dos debates produzidos no interior do próprio campo.

A igreja católica aparece requisitada no serviço de inspeção de duas formas, ocupando cargos do aparato da inspeção ou sendo convocada a auxiliar na fiscalização das escolas. O inspetor Eusébio de Queiroz, por exemplo, alegava que os professores poderiam “deixar-se dominar pelo espírito de rotina e pela indolência” quando estivessem longe da "ação da autoridade superior". Defendia a presença de autoridades que, ao exercerem "uma inspeção imediata sobre o ensino, animem o professor na árdua tarefa a que se dedicou, o aconselhem, o guiem, e o advirtam para que se não desviem do caminho que Ihes dita o dever” (p. 3). Dessa maneira, propõe o auxílio dos párocos na inspeção das escolas, ressaltando as vantagens do professor sentir-se sob dupla vigilância, a do Governo e a da Igreja:

De sua parte os professores do ensino público, e os professores e diretores dos estabelecimentos do ensino particular, sabendo que se acham constantemente sob a vigilância ativa de duas inspeções, que eles têm deveres a preencher tanto a respeito de uma como de outra, não achando apoio de um lado quando venham a estar em falta para com o outro, eram mais um estímulo eficaz para o pleno desempenho dos árduos deveres que pesão sobre a sua responsabilidade. Invoco pois a atenção de $V$. Ex ${ }^{a}$ para este melhoramento na inspeção do ensino, que julgo possível realizar-se. (Relatório relativo ao ano de 1857, p 3 )

Para o inspetor, os párocos poderiam se encarregar da vigilância quotidiana das escolas públicas e particulares, “estimulando os professores e discípulos ao cumprimento zeloso e pontual de seus deveres, dando parte à autoridade competente dos desvios da disciplina e das faltas em geral" (Relatório do ano de 1857, p. 3). No relatório do ano seguinte, Eusébio narra as iniciativas do inspetor geral interino, Desembargador Antonio da Costa Pinto, de colocar em funcionamento tal estratégia, dirigindo uma circular aos párocos, por meio da qual os convidou a fazer 
[...] uma visita geral dos estabelecimentos de educação compreendidos nas respectivas paróquias. Quase todos responderão ao convite, distinguindo-se principalmente o $\mathrm{Rv}^{\mathrm{mo}}$ Padre José do Desterro Pinto, pároco de S. Francisco Xavier do Engenho Velho, o qual visitou pessoalmente todas as aulas, escolas e casas de educação de sua paróquia, informando com reflexões mui judiciosas à inspetoria geral sobre quanto digno de atenção notou em cada um dos referidos estabelecimentos. (Relatório do ano de 1858, p. 3)

A participação dos párocos também está atrelada ao ideal de civilização e aparece como uma opção barata diante dos parcos recursos destinados à instrução. Cabe lembrar que os delegados não recebiam nenhum tipo de remuneração, mas os padres recebiam um salário do governo. Durante o império, segundo Carvalho, "o governo insistiu em não abrir mão do controle da igreja, pois além de ser ela um recurso administrativo barato (os párocos recebiam na década de 1870 um salário equivalente ao do proletariado burocrático), possuía grande poder sobre a população, de que o governo indiretamente se beneficiava" (CARVALHO, 2007, p. 187). Apesar do apelo para que a atuação da igreja católica na fiscalização fosse oficializada, clérigos estiveram presentes tanto no Conselho Diretor quanto nos cargos de delegados e de inspetor geral, ao longo da segunda metade do século XIX.

Outros sujeitos que ocuparam cargos da inspeção eram os pertencentes à ordem médica. Entre as intervenções que os médicos realizaram na vida social se destacam as que se deram via escola "enquanto lugar de cura para uma sociedade descrita sob os marcos da incivilidade, desordem, feitiçaria, curandeirismo, práticas mágicas, curiosidade e desrazão" (GONDRA, 2004, p. 83). Os médicos estenderam seu discurso para a educação em sua forma escolar com a preocupação centrada na necessidade de regeneração social. Defendiam que a educação fosse regida pelos preceitos da higiene, para assegurar que o Brasil acompanhasse o movimento do progresso. Também apresentavam a defesa de uma inspeção higiênica para monitorar o espaço escolar e os escolares "procurando, por intermédio de uma vigília constante, assegurar a manutenção de uma organização higienizada e higienizadora" (GONDRA, 2004, p. 174). 
Os bacharéis em direito constituem outro grupo presente nas engrenagens da inspeção e no governo de professores, que podem ser analisados a partir das observações realizadas acerca da formação e profissão de bacharel no século XIX. Adorno (1988) assinala que, a despeito de certos problemas, a cultura jurídica produziu um

[...] tipo específico de intelectual: politicamente disciplinado conforme os fundamentos ideológicos do Estado; criteriosamente profissionalizado para concretizar o funcionamento e o controle do aparato administrativo; e habilmente convencido senão da legitimidade, pelo menos da legalidade da forma de governo instaurada. (ADORNO, 1988, p. 91)

Homens que, a partir do governo de si, também poderiam exercer o governo do outro. Desse modo, é notável a presença na IGIPSC de pelo menos 19 bacharéis em direito no período de 1854 a 1865. O inspetor geral, que mais tempo ocupou o cargo, Eusébio de Queiroz era bacharel em direito, bem como seu auxiliar na inspeção, o secretário Theophilo das Neves Leão, que ocupou o cargo por 31 anos.

Os militares também aparecem nos cargos de inspeção. Segundo Alves (2002), o exército apresentava uma preocupação com a educação e instrução no século XIX, evidenciada pelo discurso proferido por uma intelectualidade dirigente que

[...] pensava o exército como o grande educador, aquela instituição realmente capaz de incutir os verdadeiros valores de cidadania. Esse discurso guardava íntima relação com uma série de práticas educativas que vinham sendo construídas no interior do exército desde a década de 1830. Essas práticas desdobraram-se em diversos tipos de ensino, destinados a vários públicos, incluindo militares e civis. (ALVES, 2002, p. 34)

A atuação do exército no âmbito da instrução não se limitava à formação de seus oficiais. A autora ressalta que as iniciativas e discursos a respeito desse assunto no interior da corporação, organizando um campo educativo, emergiram a partir de 1850 . Destaca que "em termos de iniciativas individuais, sabe-se da atuação de alguns militares, 
tanto do exército quanto da marinha, como escritores de textos didáticos, sobretudo em História do Brasil e Matemática" (ALVES, 2002, p. 195).

A presença de diferentes instâncias da sociedade nas engrenagens da fiscalização, como a ordem médica, jurídica, eclesiástica, militar e mesmo a docente, apontam a existência de relações de poder na organização da sociedade e dos saberes que determinam os investimentos e intervenções no exercício da docência e na escolarização da população.

\section{Considerações finais}

O processo de constituição de uma aparelhagem de inspeção na Capital do Império se deu em meio à instauração de leis, ordens, reformas que procuravam organizar um serviço considerado imprescindível na execução de um projeto de escolarização e de civilização da população, bem como na instituição de um modelo moderno de escola. Se na primeira metade do século XIX, durante o Império, um conjunto de leis e normas foram pouco a pouco sendo baixados na tentativa de efetivar a inspeção, provocando tensões e disputas entre instâncias de governo, na segunda metade do século, o Regulamento de 1854 vislumbrou “a um só golpe” estabelecer um “centro de inspeção", concentrando todas as atividades, negócios e agentes da fiscalização do ensino.

No entanto, a despeito da criação de uma Inspetoria Geral de Instrução e de agentes fiscalizadores com atribuições cuidadosamente definidas, o serviço de inspeção, após a reforma de 1854 , continuava funcionando com problemas, não sendo executado nos moldes idealizados pelos governantes, como apontam os relatórios produzidos pelos inspetores gerais e ministros do Império.

Isso não significa que a fiscalização não tenha ocorrido de maneira expressiva nem tenha produzido determinados efeitos. A reação dos professores, ao longo do século XIX, mostra uma significativa presença e intervenção da inspeção, o que demandou, por parte dos mestres, a aprendizagem de estratégias para contornar normas e a fiscalização, ou mesmo elaborar o questionamento delas. Tal fato não se deu sem tensões e conflitos entre os sujeitos envolvidos, professores, famílias de alunos e agentes da inspeção. 
Nesse sentido, insere-se a relevância de enfatizar a nomeação de pessoas por sua posição na sociedade, pela ordem que representavam, pelos interesses no âmbito da instrução, para controlar e zelar pelo bom funcionamento das escolas, contribuindo para a "missão de debelar a ignorância": bacharéis, médicos, militares, religiosos, agentes da polícia, governo, professores, cada qual desempenhando um papel bem determinado no processo de escolarização. O exercício da inspeção e o exercício da docência articulavamse no interior do exercício da governamentalidade, fazendo uso de instrumentos de fiscalização e de resistência, colocando em movimento diferentes redes de relações de poder, marcadas pelas posições ocupadas e desempenhadas em uma sociedade que se pretendia civilizada, regulada, normalizada, enfim, educada.

\section{Referências}

ADORNO, Sérgio. Os aprendizes do poder: o bacharelismo liberal na política brasileira. Rio de Janeiro: Paz e terra, 1988.

ALVES, Cláudia Maria Costa. Cultura e política no século XIX: o exército como campo de constituição de sujeitos políticos no Império. Bragança Paulista: EDUSF, 2002.

BERGER, Paulo. Introdução. In: SANTOS, Noronha. As freguesias do Rio antigo: vistas por Noronha Santos. Rio de Janeiro: O cruzeiro, 1965. p. 7-9.

BORGES, Angélica; GONDRA, José. Política e arte de superar-se: um estudo acerca das Conferências Pedagógicas na Corte Imperial. Revista de Educação Pública. Cuiabá:

EdUFMT, v. 14, n. 25, p. 203-220, 2005.

CARDOSO, Tereza Maria Fachada. Abrindo um novo caminho: o ensino mútuo na escola pública do Rio de Janeiro (1823-1840). In: BASTOS, Maria Helena Câmara; FARIA FILHO, Luciano Mendes de (Orgs.). A escola elementar no século XIX: O método monitorial/mútuo. Passo Fundo: EDIUPF, 1999, p. 119-143.

CARVALHO, José Murilo. A construção da ordem: a elite política imperial. Teatro das sombras: a política imperial. 3. ed. Rio de Janeiro: Civilização brasileira, 2007. 
ELIAS, Norbert. O processo civilizador: formação do estado e civilização. Tradução Ruy Jungmann. Rio de Janeiro: Zahar, 1993, v. 2.

FARIA FILHO, Luciano Mendes. Instrução elementar no século XIX. In: LOPES, Eliane; VEIGA, Cynthia; FARIA FILHO, Luciano M. 500 anos de educação no Brasil. Belo Horizonte: Autêntica, 2000. p. 135-150.

GIGLIO, Célia Maria Benedicto. A civilização pelo olhar: práticas e discursos da inspeção na província de São Paulo no século XIX. In: PINTASSILGO, Joaquim et al. História da escola em Portugal e no Brasil: circulação e apropriação de modelos culturais. Edições Colibri: Lisboa, 2006. p. 347-364.

GONÇALVES, Rosemari Conti. Inspeção, civilidade e progresso. In: REUNIÃO ANUAL DA ANPED, 27, 2004, Caxambu. Anais... Local: ANPEd, 2004.

GONDRA, José. Artes de civilizar: medicina, higiene e educação escolar na Corte Imperial. Rio de Janeiro: EdUERJ, 2004.

GONDRA, José. A Educação Conciliada: Tensões na elaboração, redação e implantação de reformas educacionais. Educação em questão, Natal, v. 12 e 13, p. 51-63, 2001.

GONDRA, José. O dia do professor - a ordem, a lei e as regras. Caminhando em educação - Coletânea VI, Rio de Janeiro, UERJ/Faculdade de Educação, v. 1, p. 55-61, 1997.

GONDRA, José; TAVARES, Pedro Paulo Hausmann. A Instrução reformada: ações de Coutto Ferraz nas Províncias do Espírito Santo, Rio de Janeiro e na Corte Imperial (18481854). In: CONGRESSO BRASILEIRO DE HISTÓRIA DA EDUCAÇÃO, 3, 2004, Curitiba Anais... Curitiba: PUC/SBHE, 2004. CD-ROM.

MARTINEZ, Alessandra Frota. Educar e instruir: a instrução pública na Corte Imperial (1870-1889). 1997. Dissertação (Mestrado em História) - UFF. Faculdade de História, Niterói, 1997.

MATTOS, Ilmar Rohloff. O Tempo Saquarema. São Paulo: Hucitec, 2004.

NASCIMENTO, Cecília Vieira. Do mestre à professora: estratégias de apropriação dos saberes e das práticas docentes em seu processo de profissionalização - 1872/1906. In: CONGRESSO BRASILEIRO DE HISTÓRIA DA EDUCAÇÃO, 2, 2002, Natal. Anais... Natal: SBHE/UFRN, 2002. CD-ROM.

NÓVOA, Antonio. O passado e o presente dos professores. In: NÓVOA, Antonio (Org.). Profissão professor. Porto: Porto Editora, 1991, p. 9-32.

UEKANE, Marina Natsume. Instrutores da Milícia cidadã: a Escola Normal da Corte e a formação de professores primários (1854-1889). 2008. Dissertação (Mestrado em Educação) - UERJ. Faculdade de Educação, Rio de Janeiro, 2008. 
VILLELA, Heloisa. O mestre-escola e a professora. In: LOPES, Eliane; VEIGA, Cynthia; FARIA FILHO, Luciano Mendes. 500 anos de educação no Brasil. Belo Horizonte: Autêntica, 2000, p. 95-134.

\section{Fontes usadas}

ARQUIVO GERAL DA CIDADE DO RIO DE JANEIRO, Série Instrução Pública, Códices 10.4.2 e 11.1.4.

HEMEROTECA DIGITAL BRASILEIRA, Correio Oficial, Rio de Janeiro, 1836, n. 69 e 79.

HEMEROTECA DIGITAL BRASILEIRA, Diário do Rio de Janeiro, Rio de Janeiro, 1832, n. 9 e 1843, n. 188.

Universidade do Estado de Santa Catarina - UDESC

Programa de Pós-Graduação em Educação - PPGE

Revista Linhas

Volume 18 - Número 36 - Ano 2017

revistalinhas@gmail.com 